\title{
混合構造骨組の耐震性能に関する研究 \\ STUDY ON THE ASEISMIC PERFORMANCES OF MIXED FRAME STRUCTURES
}

\author{
飯 塚信一*1，笠松照親*2，野口博*3 \\ Shinichi IIZUKA, Teruchika KASAMATSU and Hiroshi NOGUCHI
}

\begin{abstract}
In order to verify the aseismic performances of mixed frame structures, tow story - two span frame type specimens were tested. In this paper, the effects of differences of beam-column joint details on the aseismic performances were discussed. From the experimental results, the effects of the differences of the beam-column joint details were investigated on the differences of story stiffness, ultimate strength and hysteresis loops. The aseismic performances of the joint details of the through beam type was less excellent than those of the through column type. For the verification of the test results, the frame analysis of the test specimens were carried. The analytical results for the stiffness, yield strength and hysteresis loops gave a good agreement with the experimental results.
\end{abstract}

Keywords: mixed structure, frame type specimen, joint, seismic performances 混合構造、架構試験体、接合部、耐震性能

1.はじめに

柱鉄筋コンクリート（R C ）梁鉄骨（S）構造では、接合部の挙 動を検討することが重要な問題である。今まで数多くの研究機関に おいて柱梁接合部の部材実験が行われ、様々な種類の接合部形状を 有する柱 R C 梁 S 構造が開発されている。この柱 R C 梁 S 構造を実 用化するためには、柱、梁、接合部を含めた全体架構の挙動を評価 することが重要である。しかし、柱 R C 梁 S 構造架構に対する実験 的および解析的な研究例は少なく、接合部形状も限られたもので行 われているのが現状である。

西村等 ${ }^{1)}$ は、単純な梁貫通型接合部の接合部内にアンカー筋を 溶接した 1 首 2 スパンの架構試験体の実験を行い、柱 $\mathrm{R} \mathrm{C}$ 梁 S 構造 では、柱と梁の全塑性モーメントをほぼ等しくすると、S梁の剛性 がR C 柱に比べて小さいことの影響により柱の曲げモーメントの反 曲点はかなり上方に位置したことを報告している。

黒沢等 ${ }^{2)}$ は、S 梁端部をR Cで補強した 1 首 2 スパンの架構試 験体を用い、架構の塑性変形能力の解明に重点をおいた実験を行い、 実験結果から骨組は、1/100rad. で降伏したが、最大変形角は降伏 時変形角の 4 倍程度であったことを報告している。 山本等 ${ }^{3)}$ は、接合部廻りにふさぎ板を有する梁貫通型の 3 層 2 スパンの実大架構試験体の実験を行い、架構の挙動は従来の弾塑性
解析で評価でき、保有耐力は、仮想仕事法で求めた值とほぼ一致し たことを報告している。

これらの研究では、接合部形状は、梁形が貫通している接合部を 対象とした梁降伏型で、接合部のせん断少化が架構全体に与える影 響は検討されてはおらず、接合部の耐震性能をパラメータとした研 究にはなっていない。

さらに検証しているフレーム解析では、接合部を弾性または剛と 仮定して架構の挙動を評価しており、柱 R C 梁 S 構造接合部の挙動 が架構全体に与える影響を評価するものとはなっていない。 そこで本研究では、柱 R C 梁 S 構造接合部の少化状況が架構に与 える影響を検討するために、異なる接合部ディテールを有する 2 層 2 スパンの架構試験体 2 体の実験を行った。接合部ディテールは、 斜めスチフナで構成された柱貫通型接合部 ${ }^{4)}$ とエンドプレートを 有する梁貫通型接合部の 2 種類を対象とし、中柱の接合部破壊を想 定し、接合部のせん断劣化状況の違いが架構の耐震性能に与える影 響について実験的に検討を行った。

さらに既往のフレーム解析では、接合部劣化を考慮した解析がな いことから、接合部の復元力特性 ${ }^{5)}$ を考慮したフレーム解析を行 い、架構の復元力特性や破壊進行状況等の実験結果について、既往 のフレーム解析モテルの適用に際しての問題点を解析的に検討した。
*1 西松建設(侏技術研究所 係長 · 博士 (工学)

*2 西松建設侏技術研究所 研究部長.工修

*3 千葉大学工学部建築学科 教授. 工博
Technical Research and Development Institute, Nishimatsu Construction, Dr. Eng. Technical Research and Development Institute, Nishimatsu Construction, M. Eng. Prof., Dept. of Architecture, Faculty of Engineering, Chiba Univ., Dr. Eng. 


\section{2. 実験概要}

\section{1 試酫体}

試験体は、接合部ディテールのみを違えた架構試験体 2 体である。

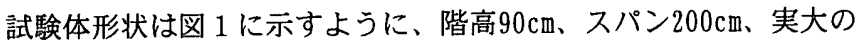
約 $1 / 3$ の 2 層 2 スパンで、柱断面はB $\times \mathrm{D}=30 \times 30 \mathrm{~cm}$ 、梁断面はBH$200 \times 100 \times 12 \times 16$ で共通である。

試験体諸元を表 1 に示す。実験パラメータは、接合部のせん断劣 化の程度の違いが架構の剛性や耐震性能に与える影響を検討するた めに、単純な梁貫通型の接合部形状 ( T B 試験体) と筆者等が提案し た斜めスチフナを有する柱貫通型の接合部形状 ( T C 試験体)である。 2 体の接合部形状を図 2 に示す。T B 試験体では、図 2 に示すよう に柱面位置にエンドプレートを有し、柱内に直交梁を有している。 TC試験体では、梁フランジをエンドプレートを介して鈶直スチフ ナ(中板ウェブと斜めスチフナ)に置き換え、接合部内中央位置の中 板ウェブを取り除いた R C 系接合部であり、直交方向は、直交梁が 取り付くことを想定したエンドプレートを有している。

柱、梁、接合部強度の関係は、筆者等が行った十字形実験 ${ }^{4)} の$ 形状と共通とし、梁降伏後の接合部破壊となる断面形状とした。ま た、接合部せん断劣化状況の違いが架構に与える影響を検討するた めに、単純な補強では強度が低めとなる T B を接合部強度が低めの 場合とし、接合部を鋼板で拘束し接合部強度が高めとなる T C を高 めの場合と設定した。十字形実験結果における接合部強度比は T B : T Cで90:130tf 程度である。

\section{2 使用材料および実鉴方法}

実験に用いたコンクリート、鉄筋、鉄骨の材料特性を表 2 に示す。 コンクリートは両試験体共通であり、実験時における圧縮強度は、 $\sigma_{\mathrm{B}}=269 \mathrm{kgf} / \mathrm{cm}^{2}$ であった。柱部分のコンクリート打設は、1 階と 2 階の各階柱中間位置に打設用の㥶を設けて、1 階、2 階の順でコ ンクリートを打設した。

鉄筋及び鉄骨も両試験体共通の材料を使用し、柱主筋には、12D19 (SD345 pt=1.28\%)、柱せ九断補強笳には、4-D10@50(SD295A

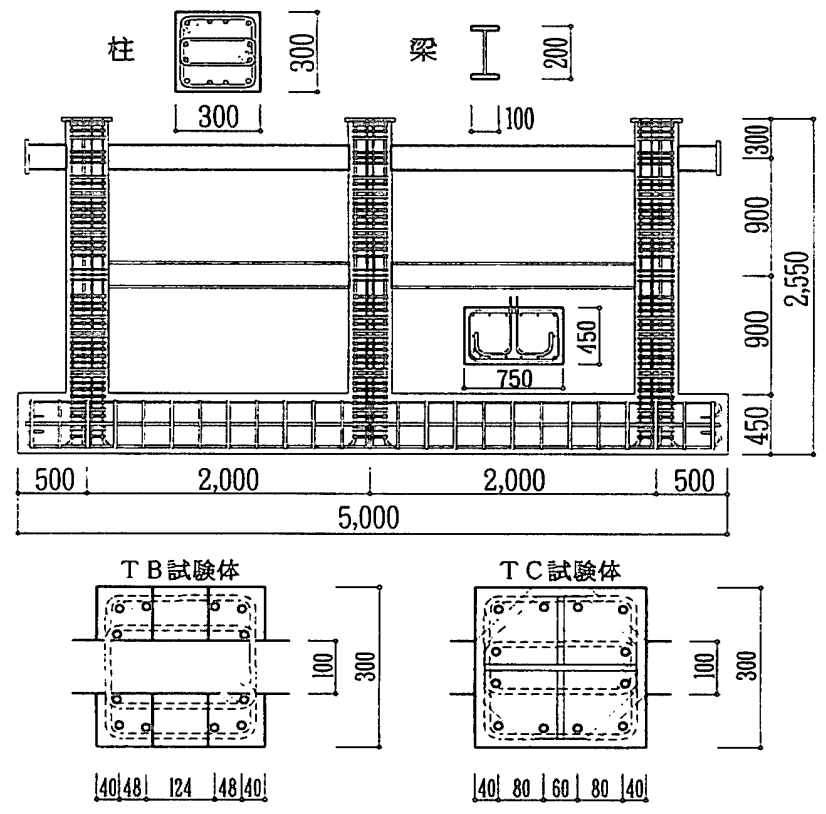

图 1 喿粠試験体形状 $\mathrm{pw}=1.9 \%)$ 、接合部せん断補強筋には、4-D6 @50(SD295A pw=0.85\%)、 梁鉄骨及び接合部鉄骨部材には、SS400を使用した。

柱軸力は、軸応力度として左右の側柱に $0.1 \sigma$ B、中央の柱に 0.2 $\sigma \mathrm{B}$ とした一定軸力を載荷できるように、各柱頂部に油圧ジャッキ をセットし、P C 鋼棒を介して柱に軸力を与えた。2 階梁位置の側 柱、中柱接合部挙動の全体架構挙動への影響を比較検討するために、 水平力は、3 階梁高さ位置の左右に設けた加力スタプに $100 \mathrm{tf} ア ク$ チュエータを取り付けて、3階梁位置のみに加えた。加力は、初め に、一定軸力を載荷し、その後、アクチュエータにより水平力を与 えた。水平力は、 $95 \mathrm{tf}$ までは、正負それぞれ片押しの加力とし、そ れ以後は、引張側のアクチュエータに水平力の約 1 割を負担させる ように加力した。載荷履歴は、中柱 3 階接合部中央高さ位置を制御 変位とした部材角 R=1/400,1/200,1/100,1/50,1/33rad. で各 3 回の 繰り返し後、部材角R=1/25 rad. で正負 1 回の加力を行った。

\section{3. 実臨結果}

\section{1 破壊経過}

T B、T C試験体の最終ひび割れ状況を図 3 に、諸荷重一覧を表 3 に示す。表中の解析值は、接合部を剛とし、柱、梁を線材置換し た架構モデルの弾塑性増分解析から求めた計算結果である。

ひび割れ状況を比較すると、1階柱脚の曲げひび割れは、両試験 体共、部材角 $R=4 / 1000 \mathrm{r}$ ad. 程度で、2 階柱の曲げひび割れは、両試 験体共、部材角 $\mathrm{R}=1 / 100 \mathrm{rad}$. 程度で発生した。接合部のせん断ひび 割れも、両試験体で発生時期に差はなく、部材角 $R=1 / 100 \mathrm{rad}$. 程度

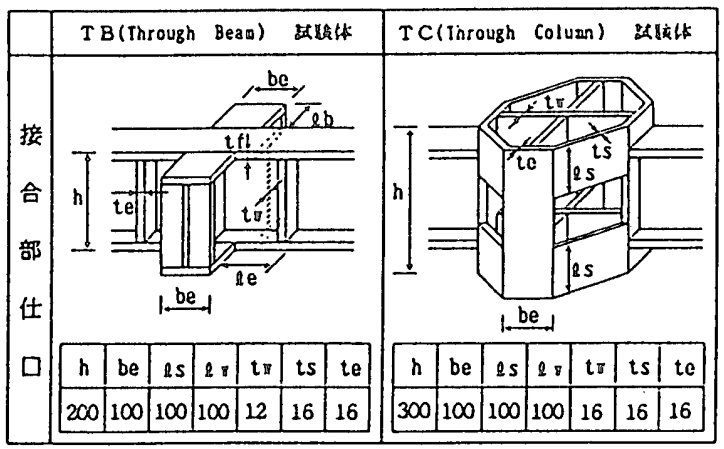

图 2 接合部形状

表 1 試験体諸元

\begin{tabular}{|l|c|c|}
\hline \multirow{4}{*}{ 柱 } & 断面 & $\mathrm{B} \times \mathrm{D}=300 \times 300(\mathrm{~mm})$ \\
\cline { 2 - 3 } & 主筋 & $12-\mathrm{D} 19\left(\mathrm{p}_{\mathrm{t}}=1.28 \%\right)$ \\
\cline { 2 - 3 } & 補强筋 & $4 \mathrm{D}-10050\left(\mathrm{p}_{\mathrm{w}}=1.9 \%\right)$ \\
\cline { 2 - 3 } & 朝力 & (侧柱) $0.1 \mathrm{BD} \sigma_{\mathrm{B}}\left(\right.$ 中桂) $0.2 \mathrm{BD} \sigma_{\mathrm{B}}$ \\
\hline 梁! & 断面 & $\mathrm{B} \mathrm{H}-200 \times 100 \times 12 \times 16(\mathrm{~mm})$ \\
\hline 接合部補强筋 & $4 \mathrm{D}-6050\left(\mathrm{p}_{\mathrm{w}}=0.85 \%\right)$ \\
\hline
\end{tabular}

表 2 材料特性

\begin{tabular}{|c|c|c|c|c|}
\hline \multicolumn{2}{|c|}{ コンクリート } & $\begin{array}{c}\text { E樎強度 } \\
\left(\mathrm{kgf} / \mathrm{cm}^{2}\right)\end{array}$ & $\begin{array}{c}\text { 引張強度 } \\
\left(\mathrm{kgf} / \mathrm{cm}^{2}\right)\end{array}$ & $\begin{array}{l}\text { ヤング係数 } \\
\left(\times 10^{5} \mathrm{kgf} / \mathrm{cm}^{2}\right)\end{array}$ \\
\hline \multicolumn{2}{|c|}{ 柱部分 } & 269 & 19. 1 & 2. 21 \\
\hline \multicolumn{2}{|c|}{ 基璴部分 } & 294 & 26.2 & 2.19 \\
\hline \multicolumn{2}{|c|}{ 銅材 } & $\begin{array}{c}\begin{array}{c}\text { 降伏強度 } \\
\left(\mathrm{kgf} / \mathrm{cm}^{2}\right)\end{array} \\
\end{array}$ & $\begin{array}{c}\text { 引張強度 } \\
\left(\mathrm{kgf} / \mathrm{cm}^{2}\right) \\
\end{array}$ & $\begin{array}{c}\text { ヤンク係数 } \\
\left(\times 10^{6} \mathrm{kgf} / \mathrm{cm}^{2}\right) \\
\end{array}$ \\
\hline \multirow{3}{*}{ 鉄筋 } & D6 & 3860 & 5435 & 1. 79 \\
\hline & D10 & 3753 & 5163 & 1.69 \\
\hline & D19 & 3854 & 5560 & 1.77 \\
\hline \multirow{2}{*}{ 铁板 } & $12 \mathrm{~mm}$ & 3124 & 4639 & 1.97 \\
\hline & $16 \mathrm{~mm}$ & 2998 & 4254 & 1.95 \\
\hline
\end{tabular}


で発生した。2 階鉄骨梁フランジの降伏は、T B 試験体では、部材 角 $\mathrm{R}=1 / 100 \mathrm{rad}$. 程度で側柱に取り付く梁フランジが降伏し、部材角 $\mathrm{R}$ $=1 / 50 \mathrm{rad}$. 程度で中柱についた梁フランジが降伏した。T C 試験体 では、部材角 $\mathrm{R}=1 / 100 \mathrm{rad}$. 程度で側柱、中柱に取り付く梁フランジ がほぼ同時期に降伏した。

コンクリートの圧壊は、両試験体共、1 階柱脚部分の圧壊が部材 角 $\mathrm{R}=1 / 33 \mathrm{rad}$. 程度から生じ始め、 T B 試験体では梁フランジのてこ 作用による接合部の圧壊が部材角 $\mathrm{R}=1 / 33 \mathrm{rad}$. 程度から、 T C 試験体 ではエンドプレートのめり込みによるコンクリートの圧壊が部材角 $\mathrm{R}=1 / 33 \mathrm{rad}$. 程度から生じた。

側柱と中柱のひび割れ状況を比較すると、両試験体共、1 階柱の 曲げひび割れ発生高さ位置が、側柱では、ほぼ柱頭位置まで達して いるのに対し、中柱では、柱高さの 7 割程度に留まっていた。

\section{2 層せん断カー層間変形関係}

図 4 に T B、T C 試験体の酋せん断力ー中柱 3 階梁位置における 全体変形関係を示す。

$\mathrm{T} \mathrm{B}$ 試験体では、履歴ループ形状が変形の増大に伴い、部材角 $\mathrm{R}=$ 1/50rad. から徐々にスリップ型の傾向を示しており、部材角 $R=1 / 33$ rad.をピークにしてそれ以降は、耐力低下がみられた。一方、T C 試験体では、最終部材角R=1/25 rad.においても耐力低下がみられず、 履歴ループ形状も変形が増大しても紡鍾型の形状を示していた。ま た、繰り返しによる耐力低下を比較すると、T B 試験体の方が T C 試験体より、繰り返しによる耐力低下の度合いが大きくなっていた。

最終的な破壊は、層せん断力一全体変形関係および部材の降伏状 況から判断すると、両試験体共、柱脚の曲げ降伏と梁フランジの降 伏とによる崩壊形と考えられる。しかし、T B 試験体では、2 階中 柱接合部の損傷も大きくなっていた。

実験結果における架構の最大耐力は、接合部を低く設定した梁貫 通型の T B 試験体で88. $5 \mathrm{t} \mathrm{f}(\mathrm{R}=1 / 33 \mathrm{rad}$. )、柱貫通型の T C 試験体で は101. $4 \mathrm{tf}(\mathrm{R}=1 / 25 \mathrm{rad}$.)であり、両試験体で約 $13 \mathrm{tf}$ 程度の差が生じ、 接合部の耐震性能を違えたことによる影響がみられた。

正側加力時における等価粘性減衰定数と部材角との関係を図 5 に 示す。両試験体は、部材角 $\mathrm{R}=1 / 100 \mathrm{rad}$.まであまり差はなく、それ 以降、部材角 $\mathrm{R}=1 / 50 \mathrm{rad}$. から T B 試験体に比べ $\mathrm{T} C$ 試験体の值が大

\section{表 3 諸荷重一筧}

\begin{tabular}{|c|c|c|c|c|c|c|c|}
\hline & \multicolumn{2}{|c|}{ T B 試駩体 } & \multicolumn{2}{|c|}{ TC試験体 } & \multicolumn{2}{|c|}{ 解析值 } \\
\hline & & 側柱 & 中柱 & 側柱 & 中柱 & 側柱 & 中柱 \\
\hline \multirow{8}{*}{ 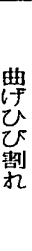 } & \multirow{2}{*}{1 䄸杜畔 } & 26.5 & 40.1 & 26.6 & 28.7 & \multirow{2}{*}{16.3} & \multirow{2}{*}{20.3} \\
\hline & & $1 / 450$ & $1 / 257$ & $1 / 514$ & $1 / 450$ & & \\
\hline & \multirow{2}{*}{1 階柱頭 } & 67.1 & $=$ & 77.1 & 74.7 & \multirow[b]{2}{*}{41.1} & \multirow[b]{2}{*}{33.4} \\
\hline & & $1 / 100$ & - & $1 / 100$ & $1 / 113$ & & \\
\hline & \multirow{2}{*}{2 僣柱脚 } & 54.3 & 67.1 & 63.7 & 77.1 & \multirow{2}{*}{42.3} & \multirow{2}{*}{30.2} \\
\hline & & $1 / 150$ & $1 / 100$ & $1 / 150$ & $1 / 100$ & & \\
\hline & \multirow{2}{*}{2 擝柱顽 } & 59.7 & 67.1 & 39.0 & 33.5 & \multirow{2}{*}{27.5} & \multirow{2}{*}{21.1} \\
\hline & & $1 / 128$ & $1 / 100$ & $1 / 300$ & $1 / 360$ & & \\
\hline \multirow{8}{*}{$\begin{array}{l}\text { 降 } \\
\text { 伏 }\end{array}$} & \multirow{2}{*}{1 照柱脚 } & 54.3 & 63.9 & 63.7 & 69.9 & \multirow{2}{*}{92.1} & \multirow{2}{*}{92.2} \\
\hline & & $1 / 150$ & $1 / 113$ & $1 / 150$ & $1 / 128$ & & \\
\hline & \multirow{2}{*}{2 僣柱㰯 } & 78.7 & 78.7 & 91.4 & 91.4 & & \multirow{2}{*}{93.4} \\
\hline & & $1 / 25$ & $1 / 25$ & $1 / 43$ & $1 / 43$ & & \\
\hline & \multirow{2}{*}{2 㫟渠 } & 75.8 & 88.5 & 69.9 & 81.8 & \multirow{2}{*}{62.2} & \multirow{2}{*}{74.4} \\
\hline & & $1 / 75$ & $1 / 33$ & $1 / 128$ & $1 / 90$ & & \\
\hline & \multirow{2}{*}{3 㫟染 } & 84.3 & 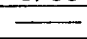 & 84.9 & 92.2 & \multirow{2}{*}{84.4} & \\
\hline & & $1 / 50$ & - & $1 / 75$ & $1 / 56$ & & \\
\hline \multicolumn{2}{|c|}{ 政大荷调 } & \multicolumn{2}{|c|}{88.5} & \multicolumn{2}{|c|}{101.4} & \multicolumn{2}{|c|}{93.4} \\
\hline
\end{tabular}

上段 荷重 (tf)、下段 部材角（rad.）解析值は、荷更のみ
きくなり、接合部の耐震性能の違いがスリップ型と紡鍾型の履歴ル ープ形状の違い及び耐力低下の度合いの違いとして表れている。

\section{3 全体降伏状況}

実験結果における鉄骨梁フランジおよび柱主筋の降伏順を図 6 に 示す。丸の中の数字は、正負共通として、初めて降伏ひずみに達し た時点における降伏順であり、その隣は、降伏時部材角を示す。

$\mathrm{T} B$ 試験体では、部材角R=1/150 rad. 〜 1/75 r ad. で柱脚が降伏し、 その後、2、3 階梁の降伏が $\mathrm{R}=1 / 75 \mathrm{rad}$ ～1/43 rad. で生じ、 $\mathrm{R}=1 / 25$ rad.の手前で 2 階柱頭が降伏した。 T C 試験体では、R=1/150 rad. １/100 rad. で柱脚が降伏し、R=1/90 rad. で 2 階梁が、その後、3 階梁の降伏がR=1/75 rad. 〜1/28 rad. で生じ、2 階柱頭の降伏がR= 1/43rad. 〜1/32rad. で生じた。

全体降伏形としては、T B 試験体では、3 階梁の降伏による降伏 形を形成しているが、T C 試験体では、 3 階梁の降伏が、やや早い

（左）（中）（右）（中）（右）

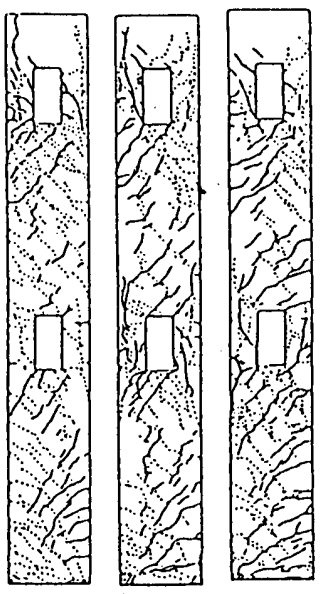

T B 試験体

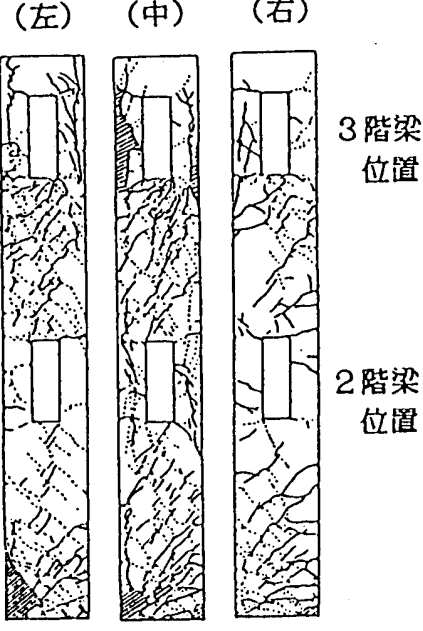

T C 試験体
図 3 最終ひび割れ状況
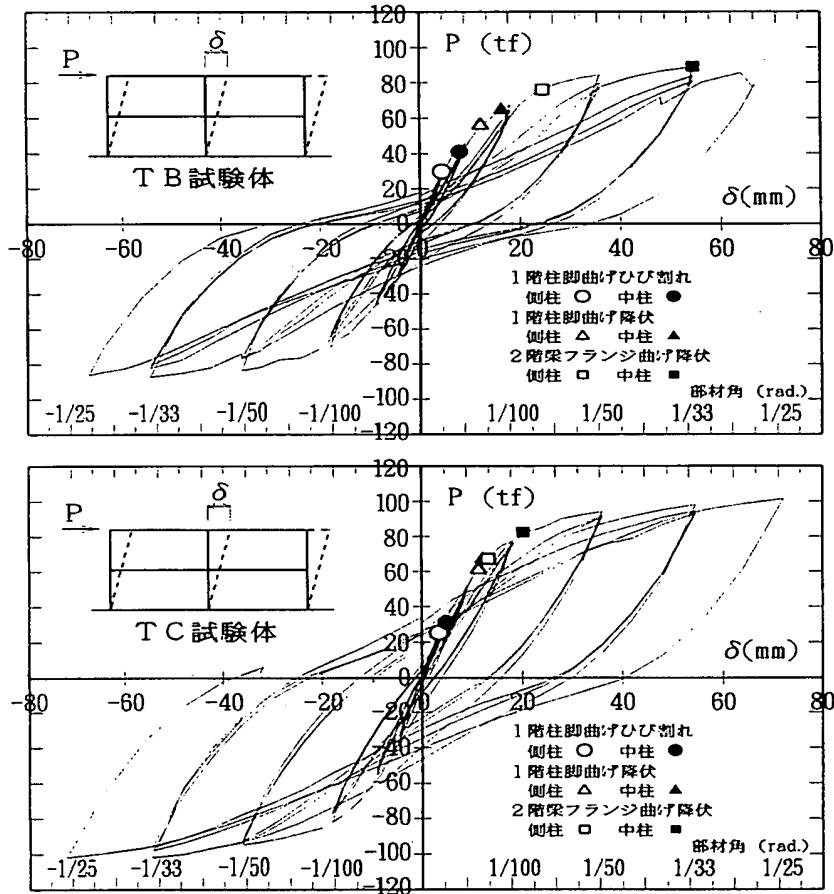

図 4 層せん断カー全体変形関係 

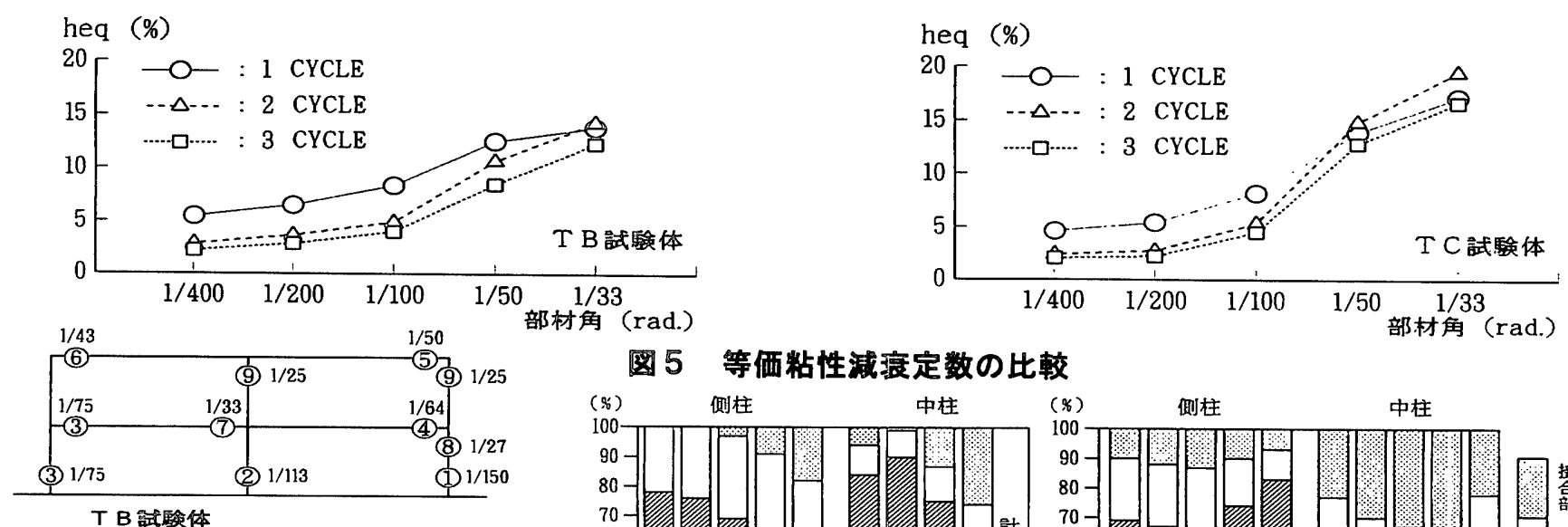

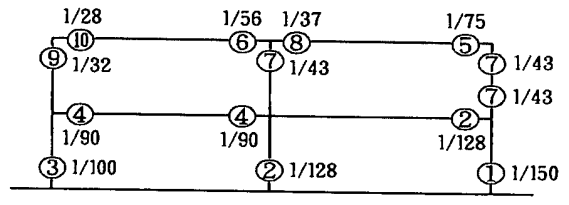

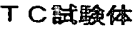

图 6 部材の降伏措祝

图 5 等価粘性減偯定数の比較

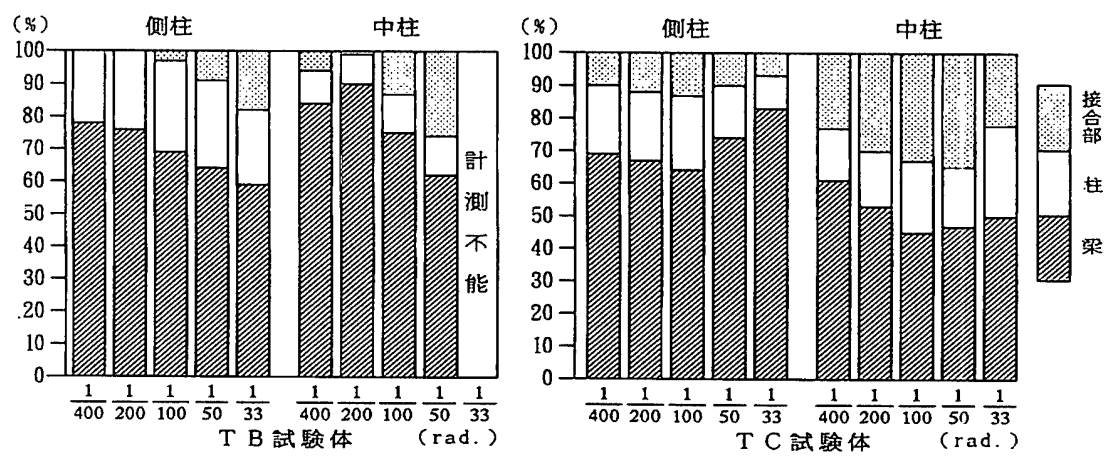

時期に降伏しているが、 2 階柱頭の降伏もほぽ同時に生じており、 3 階梁と 2 階柱頭の降伏が組み合わされた形となっている。

图 7 変形成分の割合

\section{4 変形成分}

正側加力時における側柱、中柱の 2 階位置接合部迥りの梁、柱、 接合部の変形成分の割合を図 7 に示す。ここで、梁、柱、接合部の 変形は、図 8 に示すように、試験体に取り付けた各変位計の值から 求めた。梁と接合部の変形は、接合部に取り付けた变位計による回 転量から求め、柱変形は、1、2 層の柱部材中央間の層間変形から、 梁および接合部変形を引いた值とした。 $\mathrm{T} \mathrm{B}$ 試験体では、初期にお いては、接合部変形は少なく、部材角の増大とともに接合部変形が 増加している。中柱では、側柱に比べ接合部変形は大きく、部材角 $\mathrm{R}=1 / 50 \mathrm{rad}$. では全体変形の $20 \%$ 程度であった。また、部材角 $\mathrm{R}=1 / 33$ rad. では、中柱接合部に多数のひび割れが生じ、接合部変形の計測 が不可能となった。 T C 試験体では、初期から接合部変形が現れ、 側柱では、部材角が増加してもほぼ一定の割合であるのに対して、 中柱では、接合部変形が徐々に増加し、部材角R=1/50 rad. では全体 変形の $30 \%$ 程度であった。

\section{4. 接合部举動の比較}

4. 1 接合部圧縮ストラット

モールドゲージのひずみから求めた接合部コンクリートひずみを 図 9 に示す。T B 試験体では、直交梁ウェブにより圧縮ストラット が 2 分割されていると仮定し、 T C 試験体では、接合部の対角線上 に圧䨂ストラットが生じると仮定した配置とした。図中の引張ひず みは、コンクリートの引張ひずみとひび割れ幅を含んだものである。

T B、 T C 試験体の圧縮側コンクリートひずみ量を比較すると、 T B 試験体の方が大きな值を示している。両試験体の側柱、中柱接 合部では、中柱接合部のひずみが大きく、側柱接合部の 5 倍以上の 圧縮ひずみである。中柱の圧縮ひずみ值は、コンクリートの一軸圧 縮強度時のひずみ值(約 $1800 \mu$ ) より大きな值となっている。接合部
中央のコンクリートが接合部耐力に奇与し、T B 試験体では、接合 部のせん断圧縮劣化も生じ、圧縮ひずみが急増したのに対し、TC 試験体では、接合部コンクリートが斜めスチフナにより拘束されて いるために、圧縮劣化が抑えられていることを示唆している。

\section{2 接合部降伏状況}

接合部に貼った 3 方向ゲージのひずみ值から求めた正側加力時の 接合部のせん断応力分布を図 10 に示す。計測位置は、 $\mathrm{T} \mathrm{B}$ 試験体 では、接合部内ウェブ中央位置とし、 T C 試験体では、接合部中央 位置に鉄骨ウェブが存在しないので、接合部せん断力を負担すると 考えられる直交方向エンドプレート中央位置での值である。

$\mathrm{T} \mathrm{B}$ 試験体では計測不能の点はあるが、中柱、側柱接合部を比較 すると、層間変形の小さい時点から、中柱接合部せん断応力が側柱 接合部せん断応力より大きく、中柱接合部中央位置のせん断応力が 大きな值を示し、部材角R=1/100 rad. でせん断降伏している。側柱 接合部は、最終部材角R=1/25 rad. でせん断降伏したが、それ以前の 段階では、中柱の中央部以外は、降伏に達していなかった。

$\mathrm{TC}$ 試験体でも、層間変形の小さい時から、中柱接合部直交方向 エンドプレートのせん断応力が、側柱接合部直交方向エンドプレー トのせん断応力より大きく、中柱接合部直交方向エンドプレートの せん断降伏が、部材角 $\mathrm{R}=1 / 50 \mathrm{rad}$. から生じるのに対して、側柱接合 部直交方向エンドプレートのせん断降伏は最終部材角において一部 の降伏に留まっていた。実験結果から、中柱接合部直交方向エンド プレートのせん断応力は、側柱接合部直交方向エンドプレートのせ ん断応力の 2 倍程度に達しており、梁からの入力が両側から入るこ とによる大きさの違いが接合部直交方向エンドプレートの負担せん 断力に影響を与えていることを表している。

\section{3 接合部せん断力ー接合部せん断変形角}

柱面近傍の梁フランジ上下端に貼ったひずみゲージの值から求め た梁曲げモーメントカ $(\mathrm{M})$ 及び実験值層せん断力を静的解析による 

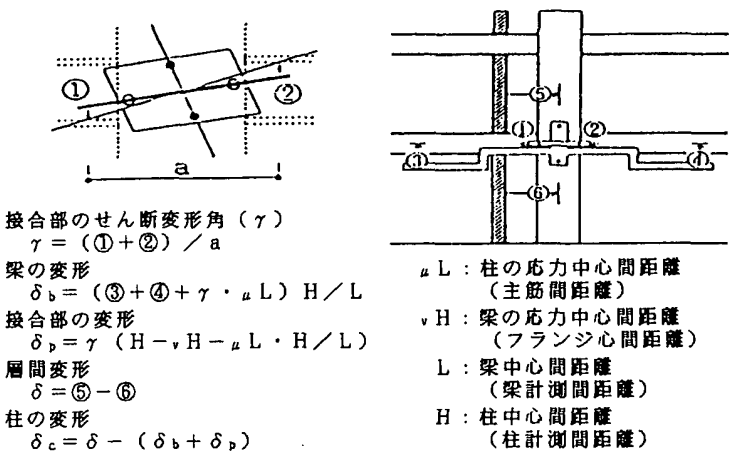

图 8 変形計測方法

側柱と中柱のせん断力負担比に分配して求めた柱せん断力 $\left(\mathrm{QC}_{\mathrm{c}}\right)$ を 用いて、接合部に作用している接合部せん断力と接合部に取り付け た変位計から求めた接合部せん断変形角の関係を図 11 に示す。

$$
\begin{aligned}
& Q_{p}=M / s \text { B } d-Q c \\
& Q_{p}: \text { 接合部せん断力 } \\
& =\sigma_{r} \cdot Z \\
& \sigma r: \text { 梁フランジ応力 } \\
& \text { Z : 断面係数 } \\
& \text { s Bd : フランジ問距雔 } \\
& \text { Qc : 柱せん断力 (静的解析結果上り) } \\
& =\text { 側柱 }(1.0 / 3.5) Q \text { 、中柱 }(1.5 / 3.5) Q \\
& \mathrm{Q} \text { ：绝せ九断力 }
\end{aligned}
$$$$
M \text { ：梁フランジひずみから求めた梁曲げモーメント }
$$

ここで、梁フランジの応力は、鉄骨部材の材料試験結果の応力一 ひずみ関係から求め、繰り返しによる履歴特性をRamberg-0sgood モデルにより考慮した。

$\mathrm{T} \mathrm{B}$ 試験体では、中柱のせん断変形が側柱に比べ、かなり大きな 変形をしており、そのループ形状は、顕著なスリップ型の性状を示 した。T C試験体では、せん断変形角 $\gamma=1 / 100 \mathrm{rad}$. から中柱の変形 が大きくなるが、スリップ時の剛性は、T B 試験体よりも大きめで あった。

T B 試験体では、接合部せん断カーせん断変形関係の履歴ループ 形状からも判るように、除荷時及び逆載荷時のスリップ量がかなり 大きく、接合部の挙動が全体架構の層せん断力ー層間変形に影響を 与えていることがわかる。T C 試験体では、T B 試験体に比ベスリ ップ時の剛性が大きく、この履歴形状の違いが、全体架構の層せん 断力ー層間変形に影響を与えていると考えられる。

\section{5. フレーム解析 \\ 5. 1 既往モデルによる解析}

架構実験結果を検討するために、図 1.2 に示すような柱、梁部材 を線材に置換したフレームモデルによる弾塑性解析を行った。

解析モデルは、接合部のせん断劣化の度合いが架構の全体挙動に 与える影響を比較するために実験結果の接合部復元力特性を考慮し た梁貫通型モデルM B 、柱貫通型モデル C である。断面及び材料 特性は共通として、架構実験の材料特性を用いて解析を行った。ま た、解析における加力は、実験における載荷履歴と共通とし、中柱 2 階梁位置の水平変位で制御した。

解析に用いた部材特性を表 4 に示す。柱部材については、R C 規 準における曲げひび割れ、降伏強度を用い、梁部材については、S

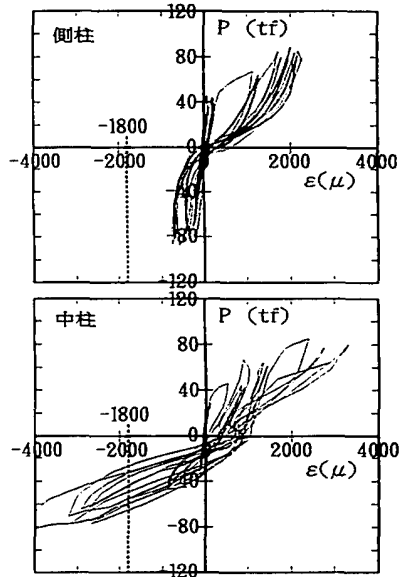

T B 試験体

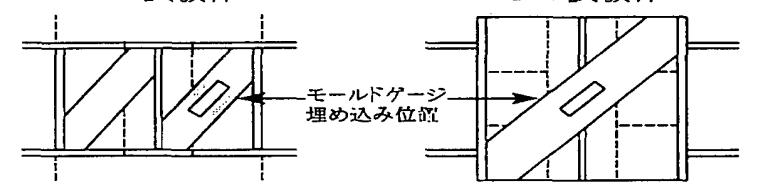

图 9 接合部コンクリートひずみ

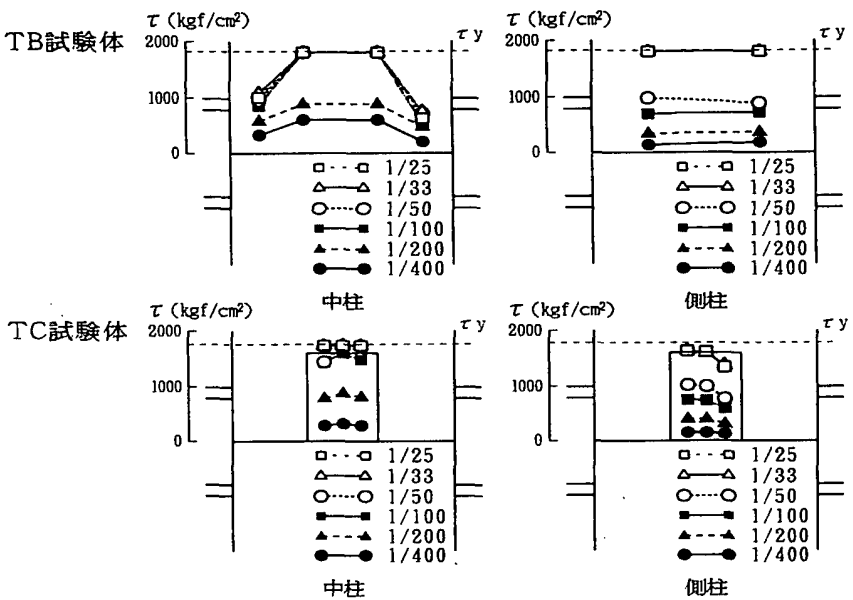

图 10 接合部のせん断応力分布
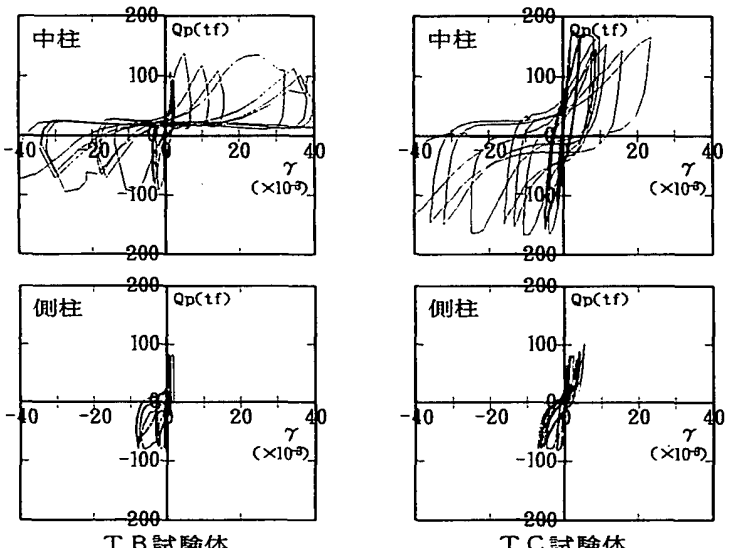

T C 試験体

图 11 接合部せん断カーせん断変形関係

規準における曲げ降伏強度を用いた。また履歴形状は、柱部材につ いてはD-Triモデル（武田モデル ${ }^{9)}$ ) を、梁部材についてはバイリ ニアモデルを用いた。

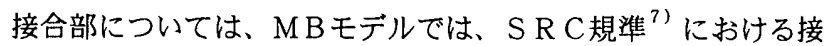
合部せん断強度を準用し、さらにせん断終局強度時のせん断変形を 坂口の研究 ${ }^{8)}$ を参考に $\gamma=4 \times 10^{-3} \mathrm{rad}$. とした復元力特性モデルと した。MCモデルでは、筆者等が行った接合部部材実験結果 ${ }^{5)}$ を 
基に、J C I 提案式 ${ }^{6)}$ を参考にして、接合部を铁骨部分とコンク リート部分に分け、それぞれの接合部せん断応力ーせん断変形関係 を重ね合わせたモデを面積が等価なトリリニア型の復元力特性に モデル化して用いた。

接合部モデル、梁フランジ芯間と柱主筋芯間を領域とし、履歷 形状のモテル化は、接合部部材実験 ${ }^{5)}$ 及び架構実験における梁貫 通型、柱貫通型の接合部せん断力ーせん断変形関係の履歴形状を参 考にした。本実験における接合部のスリップ性状の発生機構として は、接合部コンクリートストラットに沿ったひび割れの開閉による 影響が大きく、梁貫通型の方が柱貫通型より、接合部耐力を小さく 設定し、接合部コンクリートの拘束も弱いと考え、MB接合部の方 がスリップの度合いが大きいものと設定した。そこで、M B モデル では接合部のせん断劣化の影響による逆載荷時の顕著なスリップ型 を考慮し、MCモデルでは接合部仕口形状の拘束により徐々にスリ ップ型に変化していくことを考虑したD-Triスリップモデル（武田 スリップモデル）とした。 M B、M C 接合部の復元力特性モデルを

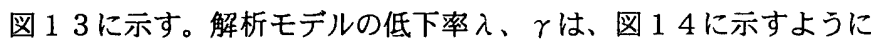
除荷剛性 K d、スリップ剛性 $\mathrm{K}$ s の割合をそれぞれ調整する係数で あり、今回の架構解析における履㭱モデルには、この低下率 $\lambda 、 \gamma$ を両試験体で異なる值を用いることでループ形状を変化させた。

接合部せん断力を求める際のコンクリート部分の有効断面積は、

S R C 規準を参考に、ひび割れ時の有効断面積を $\mathrm{Ac}=$ 柱幅 $\times$ 柱せい とし、せん断耐力時の有効断面積を $\mathrm{Ac}=($ 柱幅 $/ 2 \times$ 柱せい) とした。 鉄骨部分の有効断面積には、M Eモデルでは鉄骨ウェブ断面積を、 MCモデルでは直交方向エンドプレート断面積を用いた。

-MBモデル

せん断ひび割れ強度

$\mathrm{Q}_{\mathrm{c}}=\mathrm{Mc}_{\mathrm{c}} / \mathrm{h} \quad(\mathrm{h}$ : 梁フランジ心間距離)

$\mathrm{Mc}_{\mathrm{c}}=\mathrm{cV} \cdot 3 \mathrm{f} \mathrm{s}(1+\beta)$

$\mathrm{cV}=\mathrm{cb} \cdot \mathrm{sBd} \cdot \mathrm{mcd}$

$\mathrm{cb}:$ 柱の幅

s B d:はり鉄骨部分のフランジの重心間距離

$\mathrm{mc}$ d:柱の左右の主筋間距離

f S : コンクリートの許容せん断応力度

$\beta$ :鉄骨ウェブの形式と寸法による係数

せ九断終局強度

$\mathrm{Qu}=\mathrm{Mu} / \mathrm{h} \quad(\mathrm{h}:$ 梁フランジ心間距離 $)$

$\mathrm{Mu}_{\mathrm{u}}=\mathrm{cVe}\left(\mathrm{JFs} \cdot \mathrm{s} \delta \mathrm{t}_{\mathrm{w}} \mathrm{p} \cdot \mathrm{W} \sigma \mathrm{Y}\right)+1.2 \mathrm{sV} \cdot \mathrm{s} \sigma \mathrm{Y} / \sqrt{3}$ (3)

$\mathrm{cVe}=\mathrm{c} \mathrm{b} / 2 \cdot \mathrm{s} \mathrm{B} d \cdot \mathrm{mcd}$

$\mathrm{J} F \mathrm{~s}=\min (0.12 \mathrm{~F} \mathrm{c}, 18+3.6 \mathrm{~F} \mathrm{c} / 100)$

$\mathrm{s} V=\mathrm{s} t \mathrm{w} \cdot \mathrm{s} B \mathrm{~d} \cdot \mathrm{sc} d$

, $\delta:$ 柱はり接合部の形状による係数

$\mathrm{w} \mathrm{p}:$ 帯筋比

w $\sigma$ y:せん断補強筋の降伏応力度

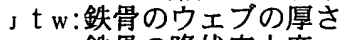

s $\sigma$ y :鉄骨の降伏応力度

scd :柱鉄骨部分のフランジの重心間距離

（計算は、scdをmcdとして行った）

- MCモテル

$\mathrm{Q}_{\mathrm{P}}=\tau_{\mathrm{C} 2} \mathrm{Act} \tau_{\mathrm{S} 2} \mathrm{As}$

コンクリートのせん断応力ーせん断変形モデル

$\tau_{\mathrm{C}_{1}=0.1 \sigma \mathrm{B}} \quad \gamma \mathrm{C}_{1}=\tau_{\mathrm{C}_{1} / \mathrm{GC}_{\mathrm{C}}}$

$\begin{array}{ll}\tau_{\mathrm{C}_{2}}=1.8 \times 0.3 \sigma_{\mathrm{B}} & \gamma_{\mathrm{C}_{2}=\left(9.2 \times 10^{-3}-\gamma_{\mathrm{C}_{1}}\right)}(\mathrm{rad})\end{array}$

$A_{c}$ ：コンクリート部分の有効断面積 $=\mathrm{c} \mathrm{b} / 2 \cdot \mathrm{s} \mathrm{B} \mathrm{d}$

$\sigma_{\mathrm{B}}:$ コンクリート圧縮強度

鉄骨のせん断応力ーせん断変形モデル

$\tau_{\mathrm{s}_{1}}=2 / 3 \cdot \mathrm{w}_{\mathrm{Y}} / \sqrt{ } 3 \quad \gamma_{\mathrm{s}_{1}}=\tau_{\mathrm{s}_{1}} / \mathrm{Gs}_{\mathrm{s}}$

$\begin{array}{ll}\tau \mathrm{s} 2=\mathrm{w} \sigma \mathrm{Y} / \sqrt{3} & \gamma \mathrm{s} 2=4 \times 10^{-3} \\ \mathrm{As}: \text { 直交エンドプレート断面積 }\end{array}$

W $\sigma$ Y : エンドプレートの降伏応力

S R C 規準によれば、接合形式(十、ト、T、L形)によりコンク リートせん断力負担分の項が $3: 2: 1$ に変化する。外柱と中柱の 接合部の扱いに関して本解析のM B モデルでは、S R C 規準に準扴

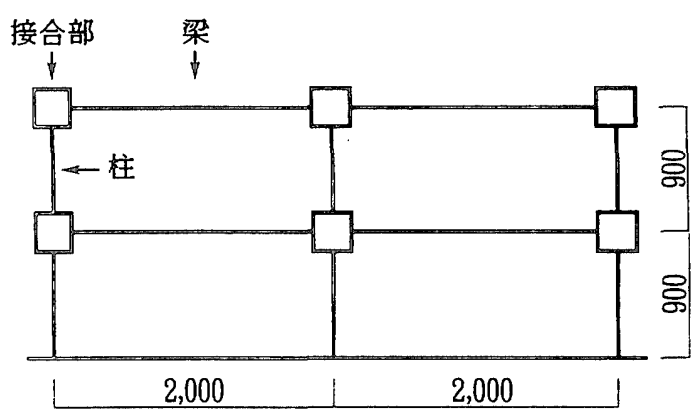

困12 解析モデル
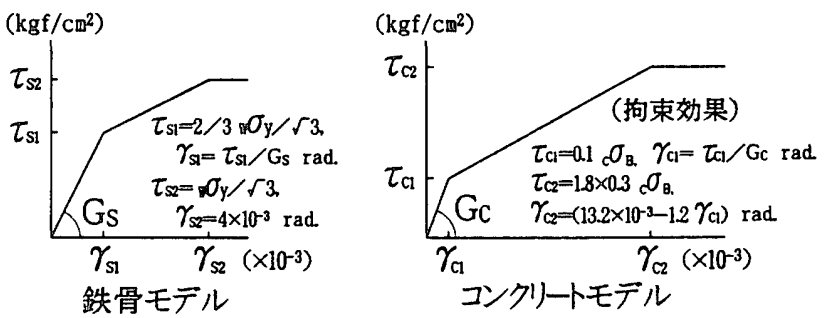

猞骨モテル

图 13 接合部復元力特性モデル（MCモデル）
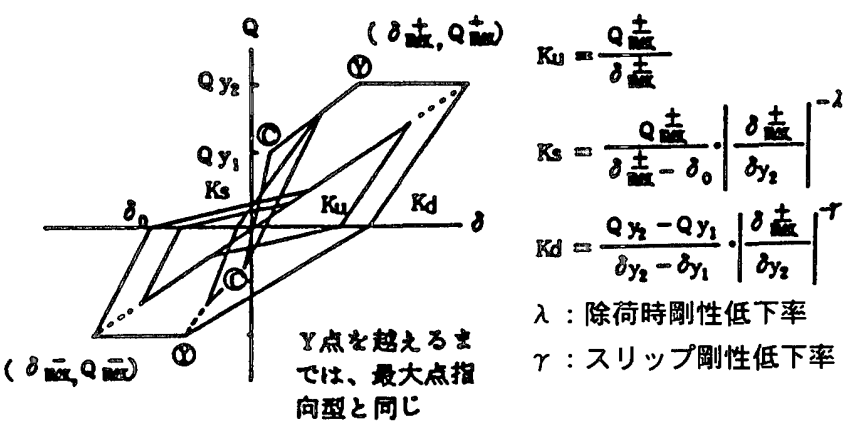

$K d=\frac{Q y_{2}-Q y_{1}}{\partial y_{2}-\delta y_{1}} \cdot\left|\frac{\partial \pm}{\partial y_{2}}\right|^{r}$

$\lambda:$ 除荷時剛性低下率

$\gamma:$ スリップ剛性低下率

図14解析モデルの係数

表 4 解析に用いた部材特性

接合部部材 $(\tau-\gamma$ モデル $)$

\begin{tabular}{|l|c|c|}
\hline & M B 接合部 & M C 接合部 \\
\hline せん断弾性剛性 $\mathrm{G}\left(\mathrm{t} / \mathrm{cm}^{2}\right)$ & 93.5 & 81.5 \\
\hline せん断ひび割れ $\mathrm{Qc}(\mathrm{t} \mathrm{f})$ & 24.0 & 23.6 \\
\hline 最大酎力Qu $(\mathrm{t} f)$ & 95.4 & 121.0 \\
\hline 除荷時剛性低下率 $(\lambda)$ & 0.001 & 0.100 \\
\hline スリップ剛性低下率 $(r)$ & 1.200 & 1.000 \\
\hline $\mathrm{Qc}$ 時せん断変形 $\left(\times 10^{-3}\right)$ & 0.29 & 0.29 \\
\hline$Q u$ 時せん断変形 $\left(\times 10^{-3}\right)$ & 4.0 & 8.9 \\
\hline
\end{tabular}

梁部材 (M- $\theta$ モデル)

\begin{tabular}{|l|c|c|c|}
\hline & MB, MC梁 & MB梁修正 & MC梁修正 \\
\hline 初期剛性 $\mathrm{K}_{0}(\mathrm{t} \cdot \mathrm{m})$ & $2.02 * 10^{3}$ & $2.02 * 10^{3}$ & $2.02 * 10^{3}$ \\
\hline 2 次剛性 $\mathrm{K}_{1}(\mathrm{t} \cdot \mathrm{m})$ & $0.001 \mathrm{~K}_{0}$ & $0.001 \mathrm{~K}_{0}$ & $0.1 \mathrm{~K}_{0}$ \\
\hline 縁降伏時My $(\mathrm{tm})$ & & 9.6 & \\
\hline 全塑性降伏時Mu $(\mathrm{tm})$ & 11.4 & 11.4 & 11.4 \\
\hline 除荷時剛性低下率 $(n)$ & & 0.001 & \\
\hline スリップ剛性低下率 $(r)$ & & 1.500 & \\
\hline
\end{tabular}

柱部材 $(M-\theta$ モデル)

\begin{tabular}{|l|c|c|}
\hline & 側柱 & 中柱 \\
\hline 初期剛性 $\mathrm{K}_{0}(\mathrm{t} \cdot \mathrm{m})$ & $1.22 * 10^{4}$ & $1.22 * 10^{4}$ \\
\hline 2次剛性 $\mathrm{K}_{1}(\mathrm{t} \cdot \mathrm{m})$ & $0.1 \mathrm{~K}_{0}$ & $0.1 \mathrm{~K}_{0}$ \\
\hline ひび割れ時My $(\mathrm{tm})$ & 3.3 & 4.6 \\
\hline 降伏時 $\mathrm{Mu}(\mathrm{tm})$ & 19.3 & 21.9 \\
\hline 除荷時剛性低下率 $(n)$ & 0.4 & 0.4 \\
\hline
\end{tabular}


して区別したが、MCモデルでは、筆者等の十字形実験結果 ${ }^{5)}$ か ら導いた接合部せん断強度を用いており、接合形式によるコンクリ 一トせん断力負担分については不明であることから、外柱も中柱と 同じ扱いにして、本解析では接合形式の違いを考慮していない。

解析結果と実験結果の層せん断力一中柱 3 階梁位置における層間 変形関係の比較を図 15 に示す。両試験体の解析結果は、紡鍾形の 履歷形状となり、M B、M モモデル共、実験結果での履歴ループの 逆 S字化を十分評価する結果にならなかった。

各部材の履歴举動から、解析結果では梁降伏により架構の耐力が 決定したと判断できる。解析結果は、接合部変形がほとんど現れず、 接合部を剛とした解析結果と同様な挙動であり、接合部部材のせん 断劣化状況を説明できず、接合部せん断劣化の度合いの違いによる 比較ができていない。解析結果が実験結果と異なった理由として、

1 ）梁変形の履歴形状において、実験結果では、梁変形の計測值は、 接合部からの梁フランジの抜け出しとめり込みによる回転変形を含 んだ形で表わされている。この影響を解析モデルは考慮していない。 2) 梁モデルでは、梁降伏後の 2 次剛性を初期剛性の $1 / 100$ とした ことにより、梁降伏以後の梁変形の増加量が大きくなり、全体架構 変形に占める梁変形の割合が大きくなっている。

柱、梁部材に既往のモデルを用いる場合には、本実験の接合部破 壊型試験体のように接合部が剛と仮定できない架構に対しては、梁 フランジの抜け出し、めり込みの影響や接合部のせん断劣化の影響 を考慮したモデル化を組み込むことが必要である。

\section{2 修正モデルによる解析}

接合部破壊型の架構の解析を行うためには、接合部自体の復元力 特性の他に、梁、柱部材のモデル化に抜け出し、めり込みによる影 響を考虑しなければならない。そこで、実験結果の各部材の履歷挙 動を検討し、梁部材のモデルを修正した。接合部せん断劣化の影響 が大きいMBモデルでは、実験結果の梁部材履歴には、梁変形に抜 け出し、めり込みによる回転変形が含まれていることを考虑し、梁 モデルの修正として、表 4 の M B 修正梁モデルに示すような、鉄骨 部材のバイリニアモデルと抜け出し、めり込みによる回転変形の組 み合わせとしたトリリニアモデルと仮定した。また、M Cモデルで は、実験結果の梁変形は、梁貫通型に比べ、抜け出し、めり込みに よる回転変形が少なく、降伏後の 2 次剛性の大きな紡鍾形を示して いることから、降伏後の梁変形の過剩な增大を防ぐことも考慮して、 梁モデルの 2 次剛性を初期剛性の $1 / 10$ としたバイリニア型とした。

解析結果と実験結果の層せん断力一中柱 3 階梁位置における層間 変形関係の比較を図 16 に示す。解析結果の層せん断力一層間変形 関係は、 T B、T C 試験体の実験結果の層せん断力一層間変形関係 と良い対応が得られるようになった。MBモデルでは、繰り返し載 荷時の履歴ループの逆 S 字化の傾向を表現でき、MCモデルでは、 紡鍾形ではあるが、履歴ループが細っている傾向が表現できるよう になった。

さらに解析結果と実験結果を比較すると、柱主筋の降伏時期は実 験の方がやや早くモデル化の違いが認められるが、柱曲げひび割れ 時期及び梁フランジ降伏時期の対応は良い。特にフランジ降伏時期 は、側柱、中柱フランジ位置の降伏時期が実験結果と同様な発生時 期となっており、解析モデルの仮定の妥当性が認められる。

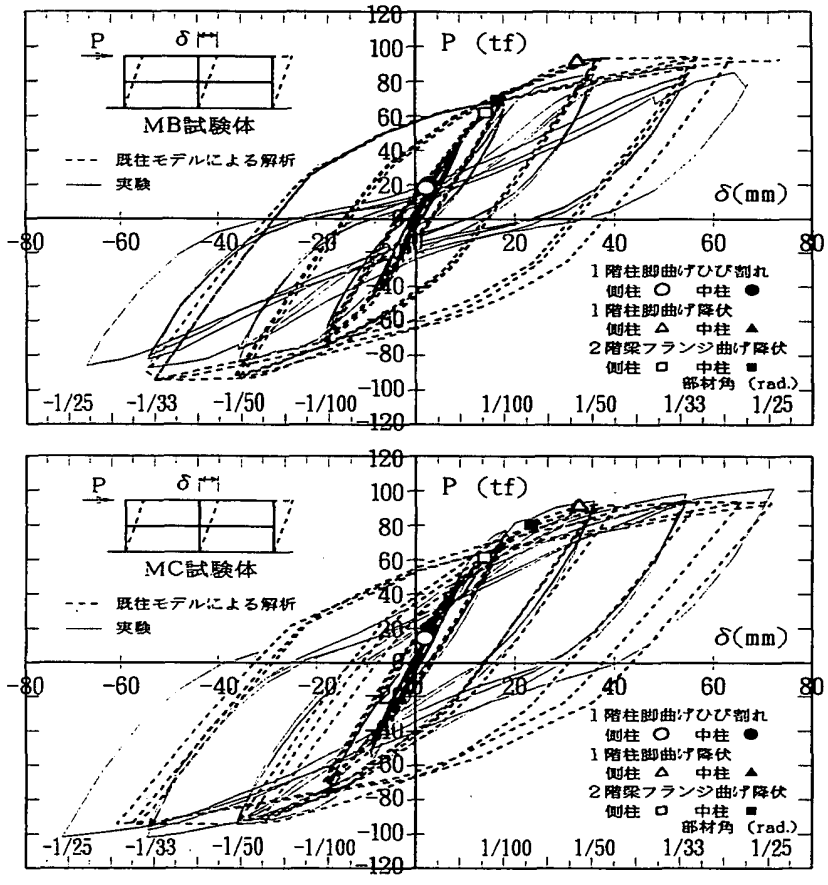

图 15 層せん断カー全体変形関係（既往モデル）
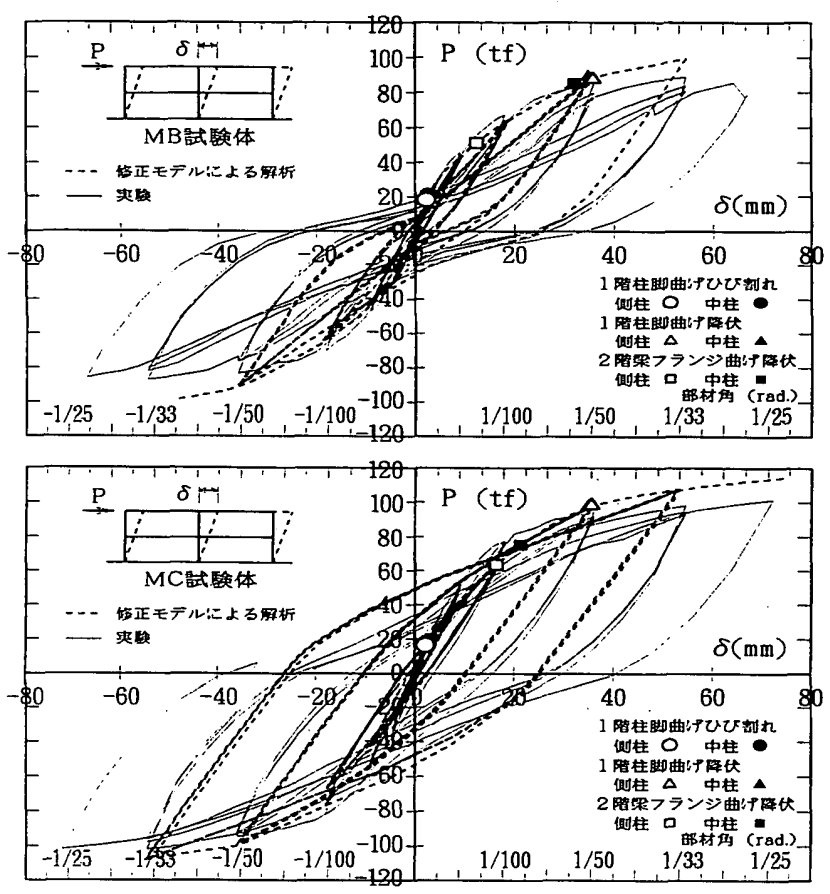

図 16 層せん断カー全体変形関係（佟正モデル）

\section{5.. 3 解析結果の検討}

解析結果の梁、接合部部材の履歷形状の比較を図 $17 、 18$ に、 降伏状況を図 19 に示す。提案モデルの接合部モデル及び修正モデ ルの梁モデル用いた解析結果における梁、接合部部材の履歴形状 は、実験結果の部材履歴形状と良い対応を示すことが認められた。

M Bモデルでは、梁部材の抜けだし、めり込みによる回転変形を 考慮することで、実験結果の紡鍾形の梁履歴挙動を表現でき、接合 部部材のせん断劣化状況をせん断変形が大きくなる部分まで表現で きた。MCモデルでは、梁部材の 2 次剛性の大きなバイリニアを表 現でき、接合部変形も正側変形が現れるようになっていきた。解析 における降伏状況は、実験に比べ 1 階柱脚部の降伏時期がやや遅い 
ものの、ほほ全体の降伏状況の傾向を表している。

架構の全体挙動を把握するためには、パラメータとした接合部復 元力特性のみならず接合部が劣化する影響による柱、梁各部材につ いての挙動も合わせてモテル化することが、実験結果の挙動をより 良好に評価させるためには必要であることが認められた。

\section{6.まとめ}

接合部破壊型で設計した接合部形式の異なる 2 体の柱 R C 梁 S 構 造架構試験体を用いて、接合部せん断劣化の程度の違いが架構に与 える影響を実験的に比較検討した。さらに、柱、梁部材を線材置換 したフレーム解析を行い、接合部破壊型柱 $\mathrm{R} \mathrm{C}$ 梁 S 構造実験結果を 解析的な側面からも検討した。検討結果から以下のことがわかった。 1) 柱 R C 梁 S 構造では、R C 柱と S 梁の部材剛性の違いが架構に 与える影響として、1 階柱の反曲点位置がかなり上方となり、柱脚 部の曲げモーメントが大きくなることが認められた。中柱接合部コ ンクリートの対角線方向の圧縮ひずみを比較すると、接合部強度を 低く設定したT B 試験体では、せん断圧縮劣化が生じていたが、高 めに設定した T C 試験体では、斜めスチフナの拘束効果により圧縮 劣化が抑えられていた。

2）接合部破壊型柱 $\mathrm{R} \mathrm{C}$ 梁 $\mathrm{S}$ 構造の接合部強度の違いが架構の耐震 性能に与える影響として、接合部強度が小さいと、架構としての剛 性が小さくなり、その影響による変形の増大、耐力の減少がみられ た。また、架構の履歴形状も接合部のせん断劣化の影響が大きくな ると、接合部の履歴形状の影響が現れることが認められた。

3) 接合部性能の違いが架構に与える影響として、強度を低めに設 定した T B 接合部では、繰返し加力における逆方向加力時のスリッ プ剛性の大きさが架構の耐震性能に影響を与え、層せん断力ー層間 変形関係もエネルギー吸収能力の小さいスリップ型の履歴形状とな ることが認められた。高めに設定した T C 接合部では、架構の耐力 低下はみられず、履歴ループも紡錘形を保持していた。接合部性能 を極端に弱くすると、架構の耐震性能が低下することが認められた。 4）接合部破壊型柱 $\mathrm{R} \mathrm{C}$ 梁 $\mathrm{S}$ 構造のフレーム解析では、接合部挙動 をモデル化し、既往の柱、梁モデルを用いた結果は、実験結果の層 せん断力一層間変形関係や部材挙動を評価することが出来ず、接合 部が劣化する影響による柱、梁各部材についての挙動も合わせてモ デル化することの必要性が認められた。この影響を考虑した修正モ テルによる解析結果は、部材挙動から架構全体挙動まで良好な対応 を示し、仮定した解析モデルの妥当性が認められた。しかし、接合 部と梁、柱部材との強度、履歷性状の関係を定量的に評価すること が、今後の検討課題として残る。

\section{謝辞}

莓造計画研究所梁川幸盛氏には、データの作成、解析計算におい てご協力を頂きました。ここに、感謝の意を表します。

\section{参考文献}

1) 妌井哲也、西村泰志、南宏一 : 柱鉄筋コンクリート・はり純鉄骨で橵成さ れる骨組の弾塑性性状（その 2 ）、日本建築学会大会学術講演梗概集、構造 II PP. $1613 \sim 1614 、 1991.9$

2）黒澤明他：地震力を受ける柱 $R C$ ／梁 S とする 1 首 2 スパンの混合構造贺 構の弾塑性性状（その 1 〜 の 3 ）、日本建筑学会大会学術講演梗概集、構造 II PP. 1887 1892、1992.8
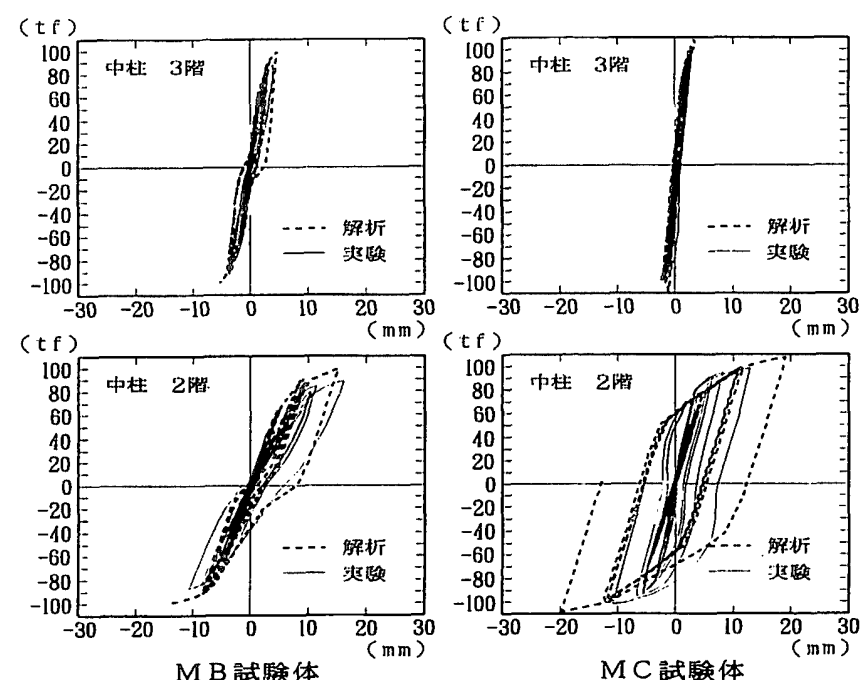

图 17 居せん断力一中柱接合部变形関係
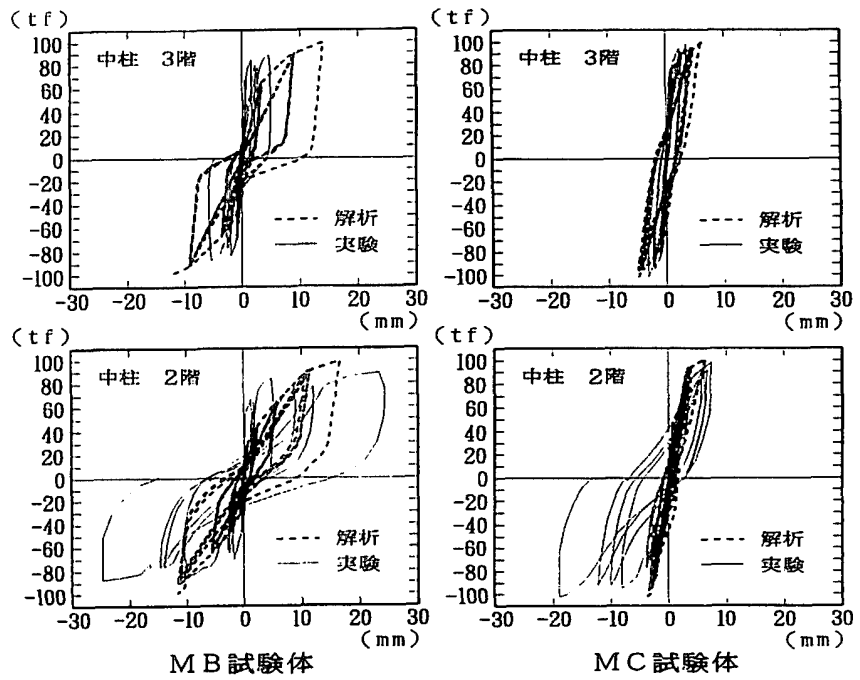

图 18 層せん断カー中柱梁変形関係

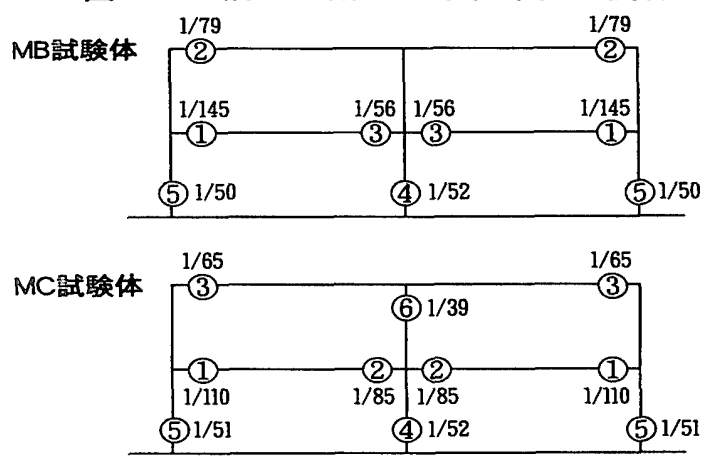

图 19 部材の降伏状況（俊正モデル）

3）山本俊彦他：混合權造（柱 R C ・梁 S）実大架構の弾塑性举動（その 1 その5)、日本建築学会大会学術講演梗概集、满造 II, PP1711 1720、1994. 9 4）飯塚信一、笠松照親、野口博：柱 R C・梁 S で構成された混合構造接合部 の耐徨性能に関する実験的研究、J C I 年次論文報告集、Vol. 15、No. 2、PP. $1019 \sim 1024,1993.6$

5）飯塚信一、笠松照親、野口博：混合構造接合部の強度と剛性に関する実驗 的研究、日本建策学会構造系論文報告集、No. 461、PP. 143 152、1994. 7

6）日本コンクリート工学協会：混合權造研究委員会報告畫、1991. 12

7) 日本建筑学会 : 鉄骨鉄筋コンクリート構造竐算規準・同解説、1 987.6

8）坂口猆：鉄能コンクリート柱と鉄骨梁で構成される柱梁接合部パネルのせ 九断力一変形関係、日本建築学会構造系論文報告集、No. 429, PP. 55 64，199.11 9) 江戸宏新、武田寿一：鉄筋コンクリート構造物の弾塑性地震応答フレーム 解析、日本建築学会大会学術講演梗概集、PP. 1877 1878，1977. 10

10）青山博之編著：鉄筋コンクリート建物の終局強度型耐霞設計法、技報堂出 版、1990.8

11）構造計画研究所：2次元フレーム解析プログラムRESP-F利用者マニュアル （1996年 6 月 10 日原稿受理，1997年 2 月13日採用決定） 